\title{
Risk Factors of Young Graduates in the Competitive E.U. Labour Market at the End of the Current Economic Crisis
}

\author{
- Kačerová Eliška
}

\begin{abstract}
Modern development trends in the labour market have been an increasingly important political and economic issue not only domestically but also on the European level. It proves the fact that in The Europe 2020 strategy, one of the main five points is the aim to increase the employment rate of the population (age: $20-64$ ) from the current $69 \%$ to at least $75 \%$. Various risk groups of job candidates emerge among the unemployed. The economic crisis in 2007 made the situation in the labour markets worse. The demand for labour decreased while the number of candidates increased. In recent years, fresh graduates under the age of 25 have been regarded as a high risk group sometimes nicknamed "the lost generation" or Generation Y. This generation is well accustomed to modern technologies which they use for their own benefit and they are willing and able to work from anywhere. On the contrary, those over the age of 35, who are sometimes referred to as Generation X, have different attitudes and requirements for the labour market. Despite the increasing level of education among young people, their unemployment has been worsening since the economic crisis began. The aim of this article was to ascertain how future university graduates (491 final-year students from 5 faculties at Tomas Bata University in Zlín, Czech Republic) perceive individual risk factors influencing the success of today's graduate of Generation $\mathrm{Y}$ in the competitive labour market. The target group, future university graduates, evaluated 13 risk areas on a five-point scale. These 13 risk areas were identified based on primary research among 1.059 employers in the Czech Republic, which is a part of a complete two-year research project IGA/FaME/2013/030. This article focuses on only two areas which closely analysed the perception of graduates as drifters, and their demands for high starting salaries. These two risk areas were mentioned by employers as the areas with the highest risk and therefore, these areas are examined in detail by the future graduates. A partial conclusion of this study indicated that future graduates, in comparison with the initial risk factor of high turnover, see much higher risk in their inability to solve problems, high initial costs of training or a lack of independence. It is the opinion of graduates, how these factors see the employers. On the other hand, graduates consider a lack of IT knowledge or few ideas/suggestions for improvement and innovation as less risky as high turnover.
\end{abstract}

Keywords: labour market, young graduates, unemployment, success, college students, risk. factors, Cz̨ech Republic JEL Classification: J220, A230, I290 


\section{INTRODUCTION}

Since 2004, when the Czech Republic joined the European Union, major changes have occurred in the European labour market in employment structures and in human resource requirements. From this year, there has been significant growth of the whole labour market, employment and wage growth. But, the situation changed dramatically in 2008, 2009 and 2010 when the economy dropped in the Czech Republic and other European countries due to the global economic crisis. At the beginning of 2005, a period of steadily declining unemployment started, lasting until the first quarter of 2008. At that time, EU-28 unemployment hit a low of 16.1 million persons (equivalent to the rate of $6.8 \%$ ) before rising sharply depends on the economic crisis. Between the second quarter of 2008 and middle of 2010, the unemployment level went up by more than 6.6 million taking the rate up to $9.7 \%$, at that time, the highest value recorded since the start of the series in 2000. The decline of unemployment in the following three quarters was a deceptive sign of the end of the crisis and of a stable improvement in labour market conditions in the EU28. In fact, from the second quarter of 2011 until the first quarter of 2013, the unemployment steadily increased taking it to the record level of 26.4 million, corresponding to the record rate of $10.9 \%$. Since then, the rate decreased, reaching $9.9 \%$ at the end of 2014 (Eurostat, 2016a). The growth in the EU-28's GDP (current prices) slowed down in 2008 and GDP decreased considerably in 2009 as a result of the global financial and economic crisis. There was a market recovery in the level of the EU-28 GDP in 2010 and this development continued (albeit at a progressively slower pace) in 2011-2013 before the growth accelerated again in 2014, as current price GDP increased by 3.0\%. By 2014, GDP in the EU-28 had reached EUR 13.9 trillion (EUR 13900 billion), that is $6.2 \%$ more than in the United States (Eurostat, 2016b). The economic crisis, however, severely hit the young. From the second quarter of 2008, the youth unemployment rate has taken an upward trend peaking in $23.8 \%$ in the first quarter of 2013 before receding to $21.4 \%$ at the end of 2014. The EU-28 youth unemployment rate was systematically higher than in the euro area between 2000 and middle of 2007 (Eurostat, 2016a). The consequences of this situation are apparent from the increasing unemployment rate of graduates who are becoming an at-risk group not only in the Czech Republic but throughout the European Union.

The introductory paragraph states that European and Czech labour market failed during the economic crisis of 2008 - 2013, and high-risk groups, including graduates, started having big problems with the application in the labour market as the statistics show. The questions then arise: Did the behaviour of young people change in the Czech Republic in relation to the labour market? What risks and opportunities are young people facing during transfer from school to work? These questions are interesting for many scientists (Helve \& Evans, 2013; Mach, Boháčková \& Selby, 2014). The article is regionally focused on behavior TBU graduates in the framework of the project Internal Grant Agency of FaME TBU No. IGA/FaME/2013/030 "Risk Factors in the Application of University Graduates on the Czech Labour Market after 2008". The aim of the primary survey among 491 future university graduates was to ascertain their evaluation of risk factors which influence success during their first employment search. This goal is subsequently presented other issues and questions. Does the evaluation of risk factor "graduates as drifters" differ between the bachelor and master's degree students? How do the students evaluate other risk factors in relation to the factor "graduates as drifters"? Are male or 
female students assuming that the employer is afraid to hire the graduate due to his/her demand for a high starting salary? The processed data was gathered through the quantitative research in 2014. This primary research is a part of a larger research that addresses the issue of risk areas from the perspectives of both sides of the labour market. A detailed research among employers is not included in this article.

Students evaluated 13 risk factors influencing their success in the Czech labour market on a scale of answers ranging from 1 (a small risk influencing success in the labour market) to 5 (a significant risk influencing success in the labour market). These 13 risk areas reported on the basis of an extensive research among Czech employers in the first phase of the project IGA, where individual factors are described thoroughly. Most factors belong to soft skills; their significance in connection with a success in the labour market present many foreign authors. As the riskiest areas, employers reported two factors: high labour turnover and high demand/high entry salary. For this reason, these factors have been examined in more detail in terms of gender and level of studies because both these play an important role in channelling young people towards gendertypical careers. The gender differentiation is a topic that is discussed in relation to the labour market for all European countries. The aim of this article is to determine whether the two identified risk areas are evaluated differently by students - men and women, and whether the perceived risk areas vary between bachelors and masters. These findings significantly help the Job Centre at the University prepare students - future graduates - to enter into the labour market.

\section{THEORETICAL BACKGROUND}

\subsection{The unemployment rate among graduates}

According to Eurostat data, the unemployment rate among graduates in the Czech labour market has increased to $19.1 \%$. This index rose by $3 \%$ in a year-on-year comparison (Radačičová, 2013). The unemployment rate of university graduates is closely connected with the overall unemployment rate in the country. It is one-third to one-half lower in most European countries, including the Czech Republic.

Lászlo Andor, the Hungarian E.U. Commissioner for Employment, Social Affairs and Inclusion, warns that unemployed young people could become a destabilizing social factor. They are already called "the lost generation" (The Economist, 2013). According to estimates, the economic loss related to young unemployed people in Europe reached 153 billion U.S. dollars, i.e., more than 1\% of GDP (The Economist, 2013). 


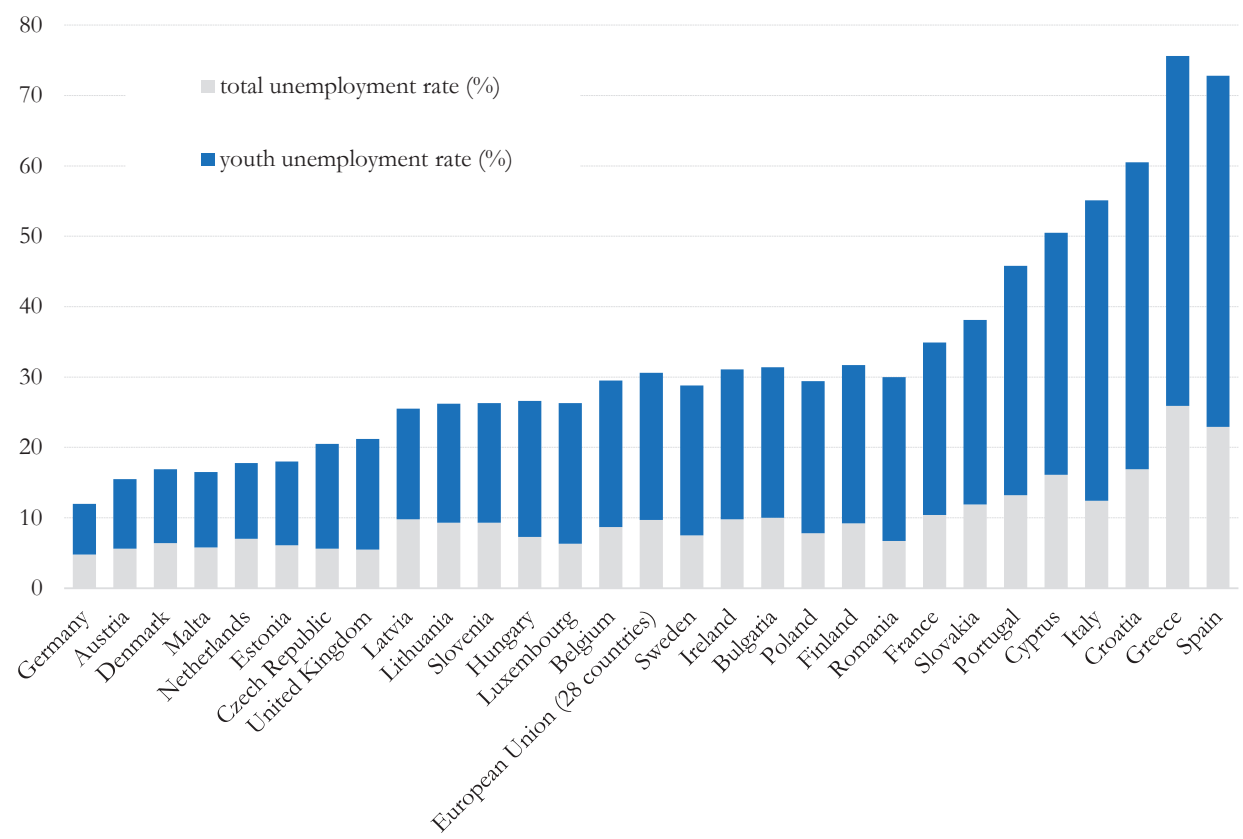

Fig. 1 - The unemployment rate in 28 States of the EU, the month of March 2015. Source: Eurostat, 2015.

The competition in the labour market in the European Union is high, especially for graduates.

\subsection{The importance of assessing the impact of risk areas on success \\ of university graduates in the labour market in the Czech Republic}

Young graduates have rarely had it easy in the labour market; however, today their situation is even worse. Despite the fact that European labour market is increasingly short of technically-oriented experts, future graduates are mostly interested in people-oriented professions, especially in business management positions (Sobotková, 2015). Modern information technologies and mass media also have significant influence on the ideas of young people regarding their future professional career (Švarcová, 2016).

In connection with the labour market mismatch, the authors often talk about over or under education. Most literature is focused on the educational mismatch and only a small percentage on the skill mismatch. Far less attention is paid to job-mismatches referring to the field of education obtained.

There are three reasons of the job-mismatch. First of all, school-leavers have to compete for the available jobs with those who have already gained a position on the labour market. Secondly, a relatively large number of school-leavers end up in jobs that do not match their educational qualification. These job-mismatches can be the result of incomplete information about the abili- 
ties of school-leavers and the characteristics of jobs offered by employers. The last possible issue of the job-mismatch deals with the imbalance of use of gained abilities and qualification (Marsíková \& Urbánek, 2015; Sloane, 2003).

Mason also identifies incomplete information as one of the reasons for problems in the labour market, reflecting a mismatch between graduates and employers (Mason, Williams \& Cranmer, 2009). According to Švarcová (2016), uncertainties in educational and occupational ambitions of students, together with the uncertainties of labour market developments, make career decision of young graduates more difficult.

Another reason of the labour market mismatch was the financial crisis which negatively affected young graduates in almost all European countries, most in Greece and Spain, where more than one-sixth of young graduates are unemployed. The economists have begun to see another problem: fresh graduates do not have the necessary knowledge and skills for the labour market (Němec, 2013).

The employability of university graduates is important theme of higher education (HE) as labour markets change more and more rapidly. The studies about employability have to consider to what degree a university education helps graduates start a career. The results of a survey of graduates from Germany indicate that the graduates possess more knowledge than required but they are missing lack important competences and transferable skills that the job market demands. This may be partly remedied by the introduction of project-oriented classes (Hennemann \& Liefner, 2010).

\subsection{Demand versus supply in the labour market}

The employers, particularly small and medium enterprises, have an irreplaceable contribution for economic growth, employment and competitiveness of each country. But, because of their size, they are sensitive to changes within external environment. Their productivity is disturbed by the existence of barriers in business that can negatively affect the employment of young graduates (Belás at al., 2014).

In order to stabilize the transition from university to the labour market, university graduates should be prepared for the requirements and needs of future employers, and their knowledge, abilities and skills (competences) should meet the expectations of their potential employers ( $\mathrm{Na}-$ tional Training Fund, 2009).

The research carried out among 50 managers of human resource departments in the Czech Republic shows that the most important factors for university graduates seeking employment are the knowledge of English (nearly 90\% of employers require English during recruitment and $57 \%$ think that university graduates should improve their English), communication skills, professional behavior, self-reliance, logical and technical thinking and good manners (Hovorková, 2012). Employers also expect the abilities to solve problems, make decisions, deal with people and to work in teams, as well as to bear responsibility, willingness to learn, adaptability, self-represention and flexibility (Kalousková \& Vojtěch, 2008).

The differences between the qualities of university graduates and employers' requirements in the labour market are increasing. Although employers generally appreciate that university graduates 
are hard-working and able to come up with original ideas, the list of required skills is still insufficient. The study carried out among 50 large Czech employers shows that university graduates lack professional experience and basic practical skills; they do not have a practical overview or experience in their fields, they lack independence and stability - high labour turnover - are extremely confident and have high financial requirements (Kalousková \& Vojtěch, 2008; Novotný, 2009).

\subsection{New Generation Y of graduates in the labour market}

The representatives of Generation Y, i.e., people born between 1980 and 1995, are today's young people in the labour market. Their motto has been characterized as, "We do not live to work, we work to live." On the other hand, they want to have meaningful jobs. They are well accustomed to modern technologies which they use for their own benefit. Due to technology, they are able and willing to work from anywhere. On the contrary, people over the age of 35 who are sometimes referred to as Generation X, have completely different attitudes and requirements for the labour market. For example, contrary to Generation Y, they are willing to work overtime more often. The priorities of graduates have been gradually changing (Hníková, 2014).

More than half of Generation Y's new graduates move back to their parents' homes after receiving their degrees, and this cushion of support gives them time to find a job that they desire. They grew up with the Internet and they know how to launch a viable online business. Generation $\mathrm{Y}$ is forcing companies to think more creatively about work-life balance. To understand Generation $\mathrm{Y}$ is important not just only for employers. Older workers, that are anyone over 30, need to know how to adapt to the values and demands of their newest colleagues. Before too long, they will be the bosses (Armour, 2005).

Terjesen identifies five most important organizational attributes for young graduates of Generation Y: they invest the most time in training and development of their employees, they care about their employees as individuals, they have clear opportunities for long-term career progression, they desire to variety in their daily work, and they have a dynamic, forward-looking approach to their business (Terjesen, Vinnocombe \& Freeman, 2007).

The most new graduates are from Generation Y, notoriously ambivalent to commitment and less loyal than their predecessors. Organisations are growing increasingly reluctant to invest in their training, particularly in transferable skills, tipping the balance of the responsibility of skill development towards higher education institutions (HEI). HEIs worldwide, however, are accused of producing graduates deficient in the "soft" skills deemed essential for enhanced productivity and innovation in the workplace (Jackson, 2010).

According to the research project REFLEX 2013, a considerable part of graduates are not prepared to offer soft skills knowledge at a level required by the employers. Especially the ability to communicate with people and the ability to manage stressful situations and obstacles are competencies that are problematic for a large part of graduates because they don't have skills on this level what is required from employer's side. What is also required are skill identify and solve problems, ability to make decisions independently, ability to take responsibility and ability to adapt to changed circumstances. For example 35\% and more of graduates are expected (required in their work), to have a high level of competence and ability to take responsibility and skills to 
communicate and negotiate with people. One third of graduates with high level of ability handle stressful situations and obstacles. $29 \%$ and more of graduates are expected high level of skills to make decisions independently to identify and solve problems. The quarter of graduates are expected high level of ability to adapt to changed circumstances, skills of flexible and creative thinking and skills to work with information. In this case, it has to accrue about 5-10\% of graduates with this high level of these competencies (Koucký, Ryška \& Zelenka, 2014).

The results of Švarcová (2016) from the year 2013, 2014 confirmed that majority of the young graduates in the CR is not interested in doing similar work as their parents. This trend may affect the structure of the workforce available for the country's economy for many years to come.

The Czech members of Generation Y are highly professionally indecisive and prefer five different professional areas, most frequently oriented towards the entertainment industry. This orientation does not fully correspond with the current Czech labour market demands, which are oriented more towards industry (Team of authors, 2013).

\section{RESEARCH OBJECTIVES AND METHODOLOGY}

The aim of the primary survey among future university graduates was to ascertain their evaluation of risk factors which influence success during their first employment search. Success in this survey is defined as the applicant's employment within six months after graduation. The target group, future university graduates, was evaluated on a five-point scale of 13 risk areas. These 13 risk areas were identified based on primary research among 1.059 employers in the Czech Republic in 2013 in the first phase of IGA research, and at the beginning of 2014 in the second phase. In the first phase, questionnaires were collected personally visits of companies by students of the Faculty of Management and Economics at Tomas Bata University. The second phase was carried out electronically.

The processed data was gathered through the quantitative research carried out at the beginning of the summer semester in February 2014. The target group consisted of students of five faculties of Tomas Bata University in Zlín, Czech Republic during their final year of studies (404 undergraduate and 87 graduate students). Altogether, 491 valid questionnaires were collected during personal visits of summer semester introduction seminars at these faculties: FAI (Faculty of Applied Informatics), FAME (Faculty of Management and Economics), FHS (Faculty of Humanities), FMC (Faculty of Multimedia Communications), and FT (Faculty of Technology).

The Students evaluated risk factors influencing their success in the Czech labour market on a scale of answers ranging from 1 (small risk influencing success in the labour market) to 5 (significant risk influencing success in the labour market). The data was consequently processed and analyzed using by various statistical computer applications.

The research sample consisted of 178 male students and 313 female students - the structure of the sample corresponds to the structure of TBU students. The questionnaire survey focused on several areas. For this article, partial risk factors influencing success at job interviews from Czech employers were selected. The analyzed areas closely included: the graduate is often perceived as a drifter, demand for high/not corresponding starting salary. These two risk areas were men- 
tioned by employers as the areas with the highest risk and therefore, these areas are examined in detail by the future graduates.

\section{Research questions and hypotheses:}

RQ1: Are bachelor/master's degree students more likely to assume that the employer perceives graduates as drifters?

$\mathrm{H}_{01}$ : The assumption of future graduates that employers perceive the graduate as a drifter is not dependent on the level of completed studies of the future university graduates.

RQ2: Do future graduates afraid of that they will not be employed because they are perceived as drifters?

$\mathrm{H}_{02}$ : All risk factors have the same degree of risk as the factor of high labour turnover.

RQ3: Are male or female students assuming that the employer is afraid to bire the graduate due to his/her demand for a high starting salary?

$\mathrm{H}_{03}$ : The assumption of future graduates that employers are afraid of non-corresponding ideas about the graduate's starting salary is not dependent on the gender of the future university graduate.

The computer program XLStatistics, and within it the Pearson Chi-square test, was used to confirm or reject the hypotheses and to answer the research questions.

\section{RESULTS AND DISCUSSION}

\subsection{The evaluation of risk areas by future university graduates}

The evaluation of risk factors influencing a success of the fresh graduate in the labour market was carried out by the quantitative research. Future university graduates assessed individual risk factors on a five-point scale. The graph below includes individual risk factors in accordance with the results from the primary February 2014 survey.

Why companies do not employ university graduates, future graduates consider the inability to solve problems (1770 points), high initial costs of training (1748 points) and lack of independence (1730 points) as the most risky criteria, while the least risky criteria are lack of IT knowledge (1325 points), few ideas/suggestions for improvement and innovation for companies (1393 points) and lack of motivation and interest (1506 points). 


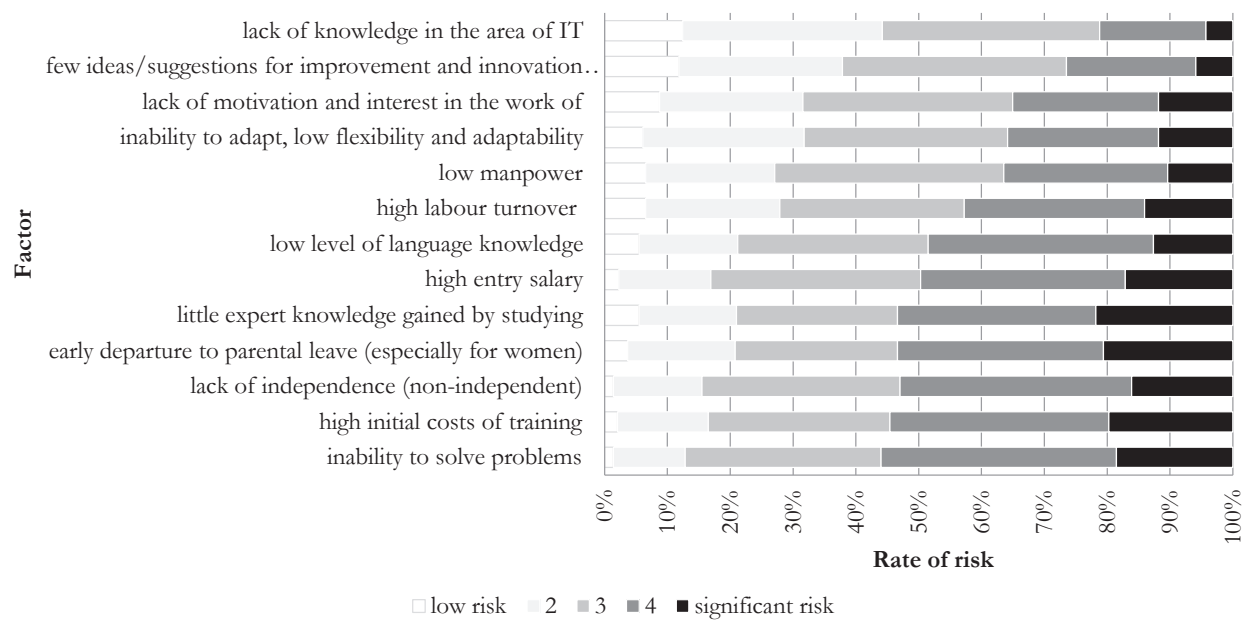

Fig. 2 - Risk factors of graduate success in the labour market. Source: own.

\subsection{A detailed evaluation of two tested risk areas}

Based on the survey results among 1.059 employers, the selected tested risk factor was that the graduate is considered to be a drifter. High turnover among fresh graduates is perceived by employers as the greatest risk. The second chosen risk factor for the closer testing was high demand/high entry salary. In this case, dependence on the gender of future graduates was examined. Gender differences play an important role in channeling young people towards gender-typical careers. However, gender continues to have a strong direct effect on labour market outcomes in both track-differentiated and general educational systems (Smyth, 2005).

The exploration analysis (the Pearson Chi-square test in XLStatistics) was chosen to verify the set hypotheses. The difference in importance of individual criteria was assessed by the t-test in the computer program XLStatistics.

$\mathbf{H}_{01}$ : The assumption of future graduates that employers perceive the graduate as a drifter is not dependent on the level of completed studies of the future university graduate.

Chi-square: 5,93336

p-value: $0,20418>\alpha$

The null hypothesis is not rejected at the level of importance of 0.05 . There was not any statistically important difference between the degree of assessment of bachelor's and master's degree students for the risk factor: high turnover.

Discussion:

Graduates like drifters are one of the subjects of interest in the article by Jiang and Loui (2012). To describe how advanced engineering students decide their post-baccalaureate plans, they conducted a mixed-methods study with engineering students at a large public university in the Mid- 
west. According to the surveys, there were no statistically significant differences between men and women in their choices of post-baccalaureate plans. Jiang and Loui (2012) reported that the drifters in their study enter professional practice without clear reasons or goals. The question is whether all TBU students have clear career plans and goals. If not, they may feel themselves as potential drifters and transmit these expectations and the expectations of employers.

Jiang and Loui (2012) defined eight decision style archetypes that characterize how students make post-baccalaureate plans - these archetypes (Avoider, Opportunist, Drifter, Planner, Pragmatist, Idealist, Tortoise, and Adventurer) can be verified by independent study under the conditions of TBU and then used to prepare students in the Job center TBU.

$\mathbf{H}_{02}$ : All risk factors have the same amount of risk as the high turnover factor.

Tab. 1 - Matrix evaluation of risk factors to the tested factor: "high turnover". Source: own

\begin{tabular}{|l|c|c|}
\hline $\begin{array}{l}\mathbf{H}_{\mathbf{0} 2}: \\
\boldsymbol{\pi}_{\mathbf{1}}-\boldsymbol{\pi}_{\mathbf{2}}=\mathbf{0}\end{array}$ & $\begin{array}{c}\overline{x_{1}}-\overline{\bar{z}_{2}} \\
\text { High turnover }\end{array}$ & Mean \\
\hline inability to solve problems & $+0,3781$ & 3,5976 \\
\hline high initial costs of training & $+0,3333$ & 3,5528 \\
\hline lack of independence & $+0,2967$ & 3,5163 \\
\hline early departure for parental leave (especially for women) & $+0,2703$ & 3,4898 \\
\hline little practical knowledge & $+0,2622$ & 3,4817 \\
\hline high demand/high entry salary & $+0,2520$ & 3,4715 \\
\hline low level of language knowledge & $+0,1199$ & 3,3394 \\
\hline high labour turnover & $\mathbf{0 , 0 0 0 0}$ & $\mathbf{3 , 2 1 9 5}$ \\
\hline low manpower & $-0,0915$ & 3,1280 \\
\hline low flexibility and adaptability & $-0,1260$ & 3,0935 \\
\hline lack of motivation and interest & $-0,1585$ & 3,0610 \\
\hline $\begin{array}{l}\text { few ideas/suggestions for improvement and innovation for } \\
\text { companies }\end{array}$ & $-0,3882$ & 2,8313 \\
\hline lack of IT knowledge & $-0,5264$ & 2,6931 \\
\hline
\end{tabular}

A different evaluation in comparison to the initial factor (high labour turnover), was identified through mutual testing of the risk factors. Future graduates, in comparison with the initial risk factor of high turnover, see much higher risk in their inability to solve problems, high initial costs of training or a lack of independence. On the other hand, a lack of IT knowledge or few ideas/suggestions for improvement and innovation are viewed as less risky than high turnover.

H03: The assumption of future graduates that employers are afraid of the graduate's salary demands does not depend on the gender of the future university graduate.

Chi-square: 5,87384

p-value: $0,20877>\alpha$ 
The null hypothesis is not rejected at the level of importance of 0.05 . There was no statistically important difference between the rate of assessment of gender for the criterion of high demand/ high entry salary.

Discussion:

Student's expectations regarding employer's requirements should be compared with the views of employers. Cai (2013) provides a conceptual framework for understanding what employers think about the value of graduates with similar educational credentials in the workplace (their employability). In this framework, the development of employer's beliefs about graduate's employability is broken into a number of factors and mechanisms, including exogenous factors, initial signalling effects and the processes of both private and public learning. The hypothesis H03 suggests that students, regardless of gender are unsure how future employers respond to their wage demands. Cai (2013) in his article provides on how to improve graduate's employment by influencing employer's beliefs using Employer-university partnerships. Closer cooperation between universities and companies during the study period can significantly affect the feasibility of the expectations of both students and employers.

\section{CONCLUSIONS}

The labour market imbalance has been increasing not only in the Czech Republic but also in other countries of the European Union. The economic crisis in 2007 worsened the situation. The downturn of Czech economy came with the end of 2008, which was consequently reflected on the Czech labour market with an increase in unemployment. On one hand, the demand for labour decreased however the number of candidates increased. In 2009, a significant deterioration in entering the labour market was experienced by university graduates who have generally been considered a risk group. They are thought to lack practical experience, and also, their positions are recently, often substitute with less educated graduates.

The aim of this article was to ascertain how future university graduates (491 final year students from 5 faculties at Tomas Bata University in Zlín) perceive individual risk factors influencing the success of today's Generation Y graduate in the labour market. The degree of dependence of two selected risk factors, gender and level of studies of future university graduates, was tested.

A partial conclusion of the study indicated that future graduates consider lack of independence or the inability to solve problems as the most significant risk factor which influencing success of a graduate in the labour market. On the contrary, they are not afraid of the lack of IT knowledge or new ideas and innovations. These results correspond with the findings of many studies and researches (Branine, 2008; Ulovec, 2014). According to the results of primary research, we can say that future graduates estimate their soft skills much more problematic by entering into the labour market as compared with hard skills (Stavjaníčková, 2015; Sobotková, 2015). It opens a space for further discussion.

The Pearson Chi-square test did not prove any statistical dependence between the degree of evaluation of masters and bachelor's degree program students for the risk factors of high turnover. This fact did not identify dependence on the degree of evaluation of gender for the risk 
factor of high demand/high entry salary. The hypothesis H03 suggests that students, regardless of gender are unsure how future employers respond to their wage demands. Cai (2013) in his article provides information on how to improve graduate's employment by influencing employer's beliefs using Employer-university partnerships. Closer cooperation between universities and companies during the study period can significantly affect the feasibility of the expectations of both students and employers.

Švarcová (2016) found in her research among university students from 2013 that respondents' gender played an important role when deciding whether to choose the same profession as their parents or not.

In the surveys of Jiang and Loui (2012), there were no statistically significant differences between men and women in their choices of post-baccalaureate plans. The authors reported that the drifters in their study enter professional practice without clear reasons or goals. The question is whether all TBU students have clear career plans and goals. If not, they may feel themselves as potential drifters and transmit these expectations and the expectations of employers.

This paper did not confirm the influence of respondents' gender on deciding on two critical risk areas from the perspective of firms (turnover and salary). The research presented in this paper identifies that the university does not have to choose different strategies for bachelors and masters on how to prepare students for the labour market. This research result will help to improve the work of the Job Centre of the University. It is not efficient to hold other preparatory activities for students - women and men, because they show a different decision, as described in the results of this study. Even this research result will help to improve the work of the Job Centre of the University. That gives the area for detailed research and testing among the other factors.

\section{Acknowledgement:}

The author is thankful to the Internal Grant Agency of FaME TBU No. IGA/FaME/2013/030 "Risk Factors in the Application of University Graduates on the Czech Labour Market after 2008" for financial support to carry out this research.

\section{References}

1. Armour, S. (2005). Generation Y: They've arrived at work with a new attitude. USA Today, 6. Retrieved from http://ora-hr.fr/sites/ora-hr.com/files/gen_y_ang.pdf

2. Belás J., Macháček J., Bartoš P., Hlawiczka R., \& Hudáková M. (2014). Business Risks and the Level of Entrepreneurial Optimism among SME in the Czech and Slovak Republic. Journal of Competitiveness, 6 (2), 30-41. http://dx.doi.org/10.7441/joc.2014.02.03

3. Branine, M. (2008). Graduate recruitment and selection in the UK. Career Development International, 13(6), 497-513, http://doi.org/10.1108/13620430810901660

4. Cai, Y. (2013). Graduate employability: A conceptual framework for understanding employers' perceptions. Higher Education, 65(4), 457-469.

5. Eurostat (2015). Harmonised unemployment rate. Retrieved from http:// ec.europa.eu/eurostat/ data/database

6. Eurostat (2016a). Unemployment statistics. Retrieved May 23, 2016, from http://ec.europa. eu/eurostat/statistics-explained/index.php/Unemployment_statistics 
7. Eurostat (2016b). National accounts and GDP. Retrieved May 23, 2016, from http://ec.europa. eu/eurostat/statistics-explained/index.php/National_accounts_and_GDP

8. Helve, H., \& Evans, K. (Eds.). (2013). Youth and work transitions in changing social landscapes. Tufnell.

9. Hennemann, S., \& Liefner, I. (2010). Employability of German Geography Graduates: The Mismatch between Knowledge Acquired and Competences Required. Journal of Geography in Higher Education, 34(2), 215-230.

10. Hníková, E. (2014). Sen absolventů: pohoda v práci. Ekonom. 13, 30-33. ISSN 1210-0714.

11. Hovorková, K. (2012). Jak se také pozná krize: Absolventi se spokojís nižšrim platem. Retrieved from http://finance.idnes.cz/absolventi-zadaji-mene-penez-di2-/podnikani. aspx?c=A120927_1834340_podnikani_zuk

12. Jackson, D. (2010). An international profile of industry-relevant competencies and skill gaps in modern graduates. IJME The International Journal of Management Education, 8(3), 29-58.

13. Jiang, A., \& Loui, M. C. (2012, October). What should I do next? How advanced engineering students decide their post-baccalaureate plans. In 2012 Frontiers in Education Conference Proceedings (pp. 1-6). IEEE.

14. Kalousková, P., \& Vojtěch, J. (2008). Potreby zaměstnavatelio a prïpravenost absolventu škol-soubrnný pobled. Národní ústav odborného vzdělávání. Retrieved from http://www.nuov.cz/uploads/ Vzdelavani_a_TP/Potreby_zamestnavatelu_souhrn.pdf

15. Koucký, J., Ryška, R., \& Zelenka, M. (2014). Reflexe v₹dèláni a uplatněni absolventu vysokých škool. Výsledky šetreni REFLEX 2013. Praha: Středisko vzdělávací politiky, Univerzita Karlova v Praze. Retrieved from http://www.strediskovzdelavacipolitiky.info/download/Reflexe $\% 2$ 0vzdelani $\% 20 \mathrm{a} \% 20$ uplatneni $\% 20$ absolventu. $\% 20$ Vysledky $\% 20$ setreni $\% 20$ REFLEX $\% 202$ 013.pdf

16. Mach, J., Boháčková, I., \& Selby, R. (2014). Knowledge or Degree?-Insight of the Czech Republic. Procedia-Social and Behavioral Sciences, 116, 3135-3141.

17. Mason, G., Williams, G., \& Cranmer, S. (2009). Employability skills initiatives in higher education: what effects do they have on graduate labour market outcomes? Education Economics, 17(1), 1-30. doi:http://dx.doi.org/10.1080/09645290802028315

18. National Training Fund. (2009). Průrkum požadavkư zaměstnavatelì na absolventy technických a prírodovédeckých oborü. Retrieved from http://www.nvf.cz/cms/assets/docs/f15ad00e2f39d62 f5226544d6042df22/150-0/pruzkum-pozadavku-zamestnavatelu.pdf

19. Němec, J. (2013). Ze školní lavice na židli státního úřadu. Ekonom. 15, 35-39. ISSN 1210 0714.

20. Novotný, P. P. (2009). Absolventi zuistávají bez práce, firmy o ně nestojí. Retrieved from http:// ekonomika.idnes.cz/absolventi-zustavaji-bez-prace-firmy-o-ne-nestoji-fvo-/ekonomika. aspx?c=A091109_195948_ekonomika_abr

21. Radačičová, S. (2013). Mladé v Evropè trápi nezaměstnanost. Nejvic bez práce json Španèlé, Réekové i Slováci. Retrieved from http://byznys.ihned.cz/c1-54904550-mlade-evropany-kosinezamestnanost-bez-prace-jich-je-5-5-milionu 
22. Sloane, P. J. (2003). Much ado about nothing? What does the overeducation literature really tell us. Overeducation in Europe, 11-45.

23. Smyth, E. (2005). Gender differentiation and early labour market integration across Europe. European Societies, 7(3), 451-479.

24. Sobotková, E. (2015). The Appeal of Business Management Positions to Czech Undergraduates. Change Management: An International Journal, 14(3-4), 13-24.

25. Stavjaničková, I. (2015). How to be a succesful graduate? Results of a comparative analysis of the Demand and Supply on the Labour Market. WSEAS Transactions on Business and Economics, 12, 1-9.

26. Švarcová, J. (2016). Macroeconomic Consequences of Contemporary Career Planning of University Students in the Czech Republic. International Journal of Interdisciplinary Social and Community Studies, 11(1), 31-42.

27. Team of authors. (2013). Partial results of the research: expert report on the interim results of the project OPVK ESF (1th ed.). Zlín: UTB.

28. Terjesen, S., Vinnicombe, S., \& Freeman, C. (2007). Attracting Generation Y graduates: Organisational attributes, likelihood to apply and sex differences. Career Development International, 12(6), 504-522. doi:http://dx.doi.org/10.1108/13620430710821994

29. The Economist. (2013). Generation jobless. The global rise of youth unemployment. Retrieved from http://www.economist.com/news/leaders/21576663-number-young-people-out-workglobally-nearly-big-population-united

30. Ulovec, M. (2014). Potreby zaměstnavateli a pripravenost absolventù škol-komparačni analýza. Retrieved from http://www.nuv.cz/uploads/Vzdelavani_a_TP/Potreby_zamestnavatelu_ komparace_2014_pro_www.pdf

31. Urbánek, V., \& Maršíková, K. (2015). A comparison of educational mismatches across Europe. E+M Ekonomie a Management, 18(4), 24-38.

\section{Contact information}

Ing. Eliška Kačerová

Tomas Bata University in Zlín

Faculty of Management and Economics

Mostni 5139, 76001 Zlin,

Czech Republic

E-mail:ekacerova@fame.utb.cz. 